\title{
To Study the Strength Characteristics of Concrete Using Waste Marble Powder and Recycled Coarse Aggregates
}

\author{
Sukhdev Vashist ${ }^{1}$, Dr. Sanjeev Naval ${ }^{2}$ \\ ${ }^{1}$ M. Tech Student, Department of Civil Engineering (Structure Engineering), DAVIET, Jalandhar, Punjab-144008 \\ ${ }^{2}$ HOD, Department of Civil Engineering, DAVIET, Jalandhar, Punjab-144008
}

\begin{abstract}
The objective of the study is to investigate the mechanical properties of concrete with different replacement levels of ordinary Portland cement by Waste marble powder and natural coarse aggregates with recycled coarse aggregates. The standard cubes (150mmX150mmX150mm) were casted. Laboratory experimentation was carried out to analyze the performance of M25 grade mix cases were casted and tested. The strength effect of concrete of various amount of replacement of cement viz., 5\%, 10\%, 15\% with Waste marble powder and various amount of replacement of natural coarse aggregates with $15 \%, 30 \%$ and $45 \%$ with Recycled coarse aggregates. The resultant concrete was tested for parameters like compressive strength, slump and workability and compared with conventional concrete.
\end{abstract}

Keywords: Concrete, Marble Powder, Recycled coarse Aggregates, Workability, Compressive Strength

\section{Introduction}

Any construction activity requires several materials such as concrete, steel, brick, stone, glass, clay, mud, wood, and so on. However, the cement concrete remains the main construction material used in construction industries. For its suitability and adaptability with respect to the changing environment, the concrete must be such that it can conserve resources, protect the environment, economize and lead to proper utilization of energy. To achieve this, major emphasis must be laid on the use of wastes and by products in cement and concrete used for new constructions[12]. Marble has been commonly used for various purposes like flooring, cladding etc., as a building material since the ancient times. The industry's disposal of the marble powder material, consisting of very fine powder, today constitutes one of the environmental problems around the world. In India, marble dust is settled by sedimentation and then dumped away which results in environmental pollution, in addition to forming dust in summer and threatening both agriculture and public health. Therefore, utilization of the marble dust in various industrial sectors especially the construction, agriculture, glass and paper industries would help to protect the environment. Recycling is the act of processing the used material for use in creating new product. The usage of natural aggregate is getting more intense with the advanced development in infrastructure area. In order to reduce the usage of natural aggregate, recycled aggregate can be used as the replacement material. Recycled aggregate comprised of crushed, graded inorganic particle processed from the materials that have been used in the construction and demolition wastes. These materials are from building, roads, bridges etc[5]. A construction industry faces a challenge when it comes to dump the constructional demolished waste. The major part of this constructional waste consists of coarse aggregates. Earlier these waste coarse aggregate were used for land filling or thrown outside locality or in water bodies. On the other hand to reconstruct a demolished structure again, the virgin coarse aggregate are used. This practice depletes the parent rocks. Now, the rate of formation of parent rock is much less than the rate of depletion. Therefore, it can be considered as a call of nature to use the recycled aggregate in construction. Further, if the recycled coarse aggregate are used in conventional construction work it would saves the cost of materials [3].

Recycled aggregate is generally produced by two stages crushing of demolished concrete, screening and removal of contaminants such as reinforcement, wood, plastic etc. RILEM Committee 121-DRG has published recommendations for the use of recycled aggregates, classifying them into three groups. Group I-Aggregates mainly from masonry rubble Group II- Aggregate obtained mainly from concrete rubble Group III-A mixture of natural aggregates $(>80 \%)$ and rubble from the other two groups (with up to $10 \%$ of group I)[4].

To address the problem of waste management in the country the Ministry of Environment and forests, Government of India constituted a committee to evolve a road map for the management of waste in India and to suggest a policy and strategy for achieving the same. .Recycling of demolished concrete is gaining importance because it protects natural resources and eliminates the need for disposal by using the readily available concrete as an aggregate source for new concrete or other applications [3]. Central Pollution Control Board reported in 2004 that solid waste generation in India was about 48 million tons/annum and more than $25 \%$ of this is from construction industry which consists of about 7-8 million tons of concrete and brick waste. The waste quantities are estimated to reach to level of atleast 85 million by 2013. RCAs is particularly very promising source of aggregates as 75 percent of any typical concrete is made of aggregates. RCAs present a unique solution to the problems of large scale demolitions occurring now-a-days in India. This recycling industry for waste concretes helps reducing management/maintenance costs of dumpsites/landfills and transportation costs [20]. The objective of this experimental 


\section{International Journal of Science and Research (IJSR) \\ ISSN (Online): 2319-7064}

Index Copernicus Value (2013): 6.14 | Impact Factor (2015): 6.391

work is to determine the strength characteristics of concrete of M25 grade with partial replacement of cement by Waste marble powder $5 \%, 10 \%$ and $15 \%$ and partial replacement of natural coarse aggregates with recycled coarse aggregates $15 \%, 30 \%$ and aggregate up to 45 percent, without affecting the design strength.[14]

\section{Material Used}

\subsection{Cement}

Ordinary Portland Cement (OPC)of 43 grade was used throughout the course of the investigation. The physical properties of the cement as determined from various tests conforming to Indian Standard IS: 1489-1991 are listed in Table 1

\subsection{Waste Marble Powder}

Marble powder was collected from the deposits of marble factories during shaping. It was sieved by IS-90 micron sieve before mixing in concrete. The properties of marble powder are given in Table 2.

\subsection{Recycled coarse Aggregates}

Recycling is the act of processing the used material for use in creating new product. The usage of natural aggregate is getting more and more intense with the advanced development in infrastructure area. In order to reduce the usage of natural aggregate,recycled aggregate can be used as the replacement materials. Recycled aggregate are comprised of crushed,graded inorganic particles processed from the materials that have been used in the constructions and demolition debris. These materials are generally from Buildings, roads,bridges, and sometimes even from catastrophes, such as wars and earthquakes. There are many advantages through using the recycled aggregate. The properties of recycled coarse aggregates are listed in Table 3.

\subsection{Aggregates}

Aggregates are those chemically inert materials which when bonded by cement paste form concrete. Aggregates constitute the bulk of the total volume of concrete and hence they influence the strength of concrete to great extent. The properties of concrete are directly related to those of its constituents and as such aggregate used in a concrete mix should be hard, strong, dense, durable, free from lumps of clays, loam, vegetable and other such foreign matter. The presence of all such debris prevents adhesion of cement on the surface of aggregates and hence reduces the strength of concrete. The aggregates are classified into two categories: fine and coarse aggregates.

\subsubsection{Fine Aggregates}

The material which passed through I.S. Sieve No. 480 $(4.75 \mathrm{~mm})$ is termed as fine aggregates. Function of fine aggregates is to make concrete dense, by filling voids of coarse aggregates, reduces the shrinkage of cement and makes an economical mix. Natural sand or crushed stone dust is used as a fine aggregate in concrete mix. Sand may be obtained from sea, river, lake or pit, but when used in a concrete mix, it should be properly washed and tested to ascertain that total percentage of clay, silt, salts and other organic matter does not exceed specified limit. Sand as obtained from the above sources may be round or angular in grains. Angular grained sand has good interlocking property which results in a strong mix while rounded grained sand does not afford sufficient interlock in the matrix.

\subsubsection{Coarse Aggregates}

The material whose particles are of such size as are retained on I.S. Sieve No. $480(4.75 \mathrm{~mm})$ is termed as coarse aggregates. Coarse aggregates, like fine aggregates, must consists of sound durable inert particles to make the concrete strong and weather resistant. It should be free chemicals or coating or clay or other fine material that may affect bonding of cement paste. The size of the coarse aggregates used depends upon the nature of work. Crushed hard stone and gravel are the common materials used as coarse aggregates for structural concrete. Coarse aggregates are usually obtained by crushing granite, gneiss, crystalline lime stone and good variety of sand stone etc. As far as possible flaky and elongated pieces of stone should be avoided. The properties of coarse aggregate are given in Table 5.

\section{Mix Design}

A mix M25 Grade of concrete was designed as per IS1026:2009 method and the same was used to prepare the test samples. The weights of various constituent materials per $\mathrm{m} 3$ of concrete are given in Table 6 .

\section{Experimental Methodology}

\subsection{Workability of Concrete Mixes}

Workability is the most elusive property of concrete. In simplest form, a concrete is said to be workable if it can be easily mixed, handled, transported, placed in position and compacted. More precisely, it defines that it can be fully compacted with minimum energy input. There should be no sign of any segregation or bleeding in a workable concrete. In this experiment slump of all mixes with constant water to cementitious material $(\mathrm{w} / \mathrm{cm})$ ratio for the same group were measured to get information about workability changes due to the waste marble powder and recycled coarse aggregate.As it is shown in Table 7.

\subsection{Compressive Strength Test}

Compressive strength tests were conducted on concrete cubes of size $150 \times 150 \times 150 \mathrm{~mm}$ cast from concrete of each series, to check quality by obtaining the 28-days compressive strength. These tests were carried out in accordance with IS: 516-1959 on Compression Testing Machine . The maximum compressive load on the specimen was recorded as the load at which the specimen failed to take any further increase in the load. The average of three samples was taken as the representative value of compressive strength. The compressive strength was calculated by dividing the maximum compressive load by the cross-sectional area of the cube specimen. 


\section{International Journal of Science and Research (IJSR) \\ ISSN (Online): 2319-7064}

Index Copernicus Value (2013): 6.14 | Impact Factor (2015): 6.391

The results of the compressive strength tests conducted on concrete specimens of different mixes cured at different ages are shown in table 8 . The compressive strength test was conducted at curing ages of 7 days and 28 days.

\section{Results}

It can be noted that when marble powder is substituted as binder with cement and crushed tile aggregate is substituted as filler with coarse aggregate, the compressive strength was found to increase at lower replacements. The 7-days and 28 days compressive strength of concrete mix containing $5 \%$ of marble powder and $15 \%$ crushed tile aggregate were found to increase from a value $21.23 \mathrm{~N} / \mathrm{mm}^{2}$ to $22.55 \mathrm{~N} / \mathrm{mm}^{2}$ and $33.67 \mathrm{~N} / \mathrm{mm}^{2}$ to $34.87 \mathrm{~N} / \mathrm{mm}^{2}$. With the increase in the percentage of replacement of recycled coarse aggregate from $15 \%$ to $30 \%$, there is again an increase in the 7-days and 28 days compressive strength from $22.55 \mathrm{~N} / \mathrm{mm}^{2}$ to $23.16 \mathrm{~N} / \mathrm{mm}^{2}$ and $34.87 \mathrm{~N} / \mathrm{mm}^{2}$ to $35.64 \mathrm{~N} / \mathrm{mm}^{2}$. It shows that using Recycled coarse aggregate as coarse aggregate cause increase in the strength of concrete upto 30 percent replacement, but after $30 \%$ replacement, strength starts decreasing from $23.16 \mathrm{~N} / \mathrm{mm}^{2}$ to $21.73 \mathrm{~N} / \mathrm{mm}^{2}$ and 35.64 $\mathrm{N} / \mathrm{mm}^{2}$ to $34.06 \mathrm{~N} / \mathrm{mm}^{2}$. The reason for decreasing the strength of samples as a result of enhancing the amount of RCA may due to increase in flaky aggregates and due to smooth surface texture of tile aggregate and poor bonding properties of matrix with matrix with aggregate.

Figures (6\&7) show that by increasing the percentage of replacement of waste marble powder with cement, the compressive strength values of concrete tends to increase at each curing age. The 7-days and 28 days compressive strength of concrete mix containing $5 \%$ of marble powder and $15 \%$ crushed tile aggregate were found to increase from a value $21.23 \mathrm{~N} / \mathrm{mm}^{2}$ to $22.55 \mathrm{~N} / \mathrm{mm}^{2}$ and $33.67 \mathrm{~N} / \mathrm{mm}^{2}$ to $34.87 \mathrm{~N} / \mathrm{mm}^{2}$. With the increase in the percentage of replacement of waste marble powder from $5 \%$ to $10 \%$, there is again an increase in the 7-days and 28 days compressive strength from $22.55 \mathrm{~N} / \mathrm{mm}^{2}$ to $22.89 \mathrm{~N} / \mathrm{mm}^{2}$ and $34.87 \mathrm{~N} / \mathrm{mm}^{2}$ to $35.44 \mathrm{~N} / \mathrm{mm}^{2}$. The increase in the value of compressive strength at 7 -days and 28 days curing period can be attributed to the fact that marble granules possess cementing properties. It is also as much effective in enhancing cohesiveness due to lower fineness modulus of the marble powder. or granules both. However, there is a decrease in compressive strength values (7-days \& 28 days) of concrete mix from $22.89 \mathrm{~N} / \mathrm{mm}^{2}$ to $20.01 \mathrm{~N} / \mathrm{mm}^{2}$ and $35.44 \mathrm{~N} / \mathrm{mm}^{2}$ to $33.18 \mathrm{~N} / \mathrm{mm}^{2}$, when $15 \%$ marble powder is replaced with cement and $15 \%$ recycled coarse aggregate replaced with coarse aggregate in control mix. These decreases in strength mainly occur due to that with further increase in replacement of marble powder with cement results in the replacement of Portland cement clinker with powder addition with different proportion which causes dilution of $\mathrm{C}_{3} \mathrm{~S}$ and $\mathrm{C}_{2} \mathrm{~S}$ which is responsible for strength.

\section{Conclusion}

- As the partial replacement level of waste marble powder with cement in concrete increases, workabilkity decreases.
- Same effect on the workability of concrete can be seen for the partial replacement of coarse aggregates with recycled coarse aggregates.

- Compressive Strength of concrete increases upto $10 \%$ of partial replacement of Cement with waste marble powder and upto $30 \%$ of partial replacement of coarse aggregates with recycled coarse aggregates.

- There is a decrease in the compressive strength of concrete if the replacement level increased from $10 \%$ to $15 \%$ for waste marble powder and $30 \%$ to $45 \%$ of recycled coarse aggregates

- Same effect on the workability of concrete can be seen for the partial replacement of coarse aggregates with recycled coarse aggregates.

\section{References}

[1] HanifiBinici, Hasan Kaplan and SalihYilmaz, (2007), "Influence of marble and limestone dusts as additives on some mechanical properties of concrete," Scientific Research and Essay, 2(9), pp 372379.

[2] C P Y and L C D T (2009). Utilization of Recycled Aggregate as CoarseAggregate in concrete. UNIMAS E- Journal of Civil Engineering, Vol.1, Issue 1, Aug., 2009.

[3] Dabhade, A.N., Chaudari, R. S., and Gajbhaye,R. A., (2013). Effect of Pozzolonic Material on Split Tensile Strength of Recycle Aggregate Concrete. International Journal of Engineering Science and Innovative Technology. Vol.2,Issue 5, Sep., 2013 : 476-479.

[4] Deshpande, K. N., Kulkarni, S. S., and PachpandeH. (2012). StrengthCharacteristics of Concrete with Recycled Aggregates and Artificial Sand. International Journal of Engineering Research andApplications, Vol.2, Issue 5 (Sep-Oct., 2012),PP 38-42.

[5] Dabhade, N. A., Choudari, R. S., and Gajbhiye,R. A. (2012). Performance Evaluation of Recycled Aggregate used in Concrete.International Journal of Engineering Research and Applications, Vol.2, Issue 4 (Jul-Aug., 2012), PP 1387-1391.

[6] Ephraim, E. M., Akeke, A. G., Ukpata,O. J.,(2012). Compressive strength ofConcrete with rice husk ash as partial replacement of ordinary Portland cement.

[7] Scholarly Journal of Engineering Research. 1 (2) : 3236.62 International Journal for Science, Management and Technology ISSN: 2395- 5856

[8] Hameed M S and Sekar A S S (2009) Properties of Green Concrete containing Quarry Rock Dust and Marble Sludge powder as a fine aggregate ARPN J Engineering Applied Sciences4: 83-89.

[9] HanifiBinici, Hasan Kaplan and SalihYilmaz, (2007), "Influence of marble and limestone dusts as additives on some mechanical properties of concrete," Scientific Research and Essay, 2(9), pp 372379.

[10] He, J. Z., and Zhang, X. J., (2013). Strength Characteristics and failure criterion of plain recycled aggregate concrete under triaxial stress states. Construction and Building Materials. 54(2014): 354 362.

[11] Indian Standard IS: 516-1959. Methods of tests for Strength Of Concrete- Bureau of India Standards, Manak Bhawan, 9 Bahadur Shah Zafar Marg, New Delhi 110002. 


\section{International Journal of Science and Research (IJSR) \\ ISSN (Online): 2319-7064 \\ Index Copernicus Value (2013): 6.14 | Impact Factor (2015): 6.391}

[12] Indian Standard IS 383-1970. Specification for Coarse and Fine aggregates from Natural sources for concrete Bureau of India Standards, Manak Bhawan, 9 Bahadur Shah Zafar Marg, New Delhi 110002.

[13] Indian Standard IS: 10262-2009. Concrete mixproportioning- Bureau of India Standards,Manak Bhawan, 9 Bahadur Shah Zafar Marg,New Delhi 110002.

[14] Indian Standard IS: 4031-1988. Methods of physical tests for hydraulic cement- Bureau of India Standards, Manak Bhawan, 9 Bahadur Shah Zafar Marg, New Delhi110002.

[15] Indian Standard IS: 1489-1991(Part- 1). Portlandpozzolana cement specification- Bureau of India Standards, Manak Bhawan, 9Bahadur Shah Zafar Marg, New Delhi 110002.

[16] Indian Standard IS 456-2000. Plain and Reinforced Concrete- Bureau of India Standards, Manak Bhawan, 9 Bahadur Shah Zafar Marg, New Delhi 110002.

[17] Kishore, R., Bhikshma, V., and Prakash, J. P.,(2011). Study on Strength Characteristics of High Strength Rice Husk Ash Concrete. Procedia Engineering 14(2011): 2666-267.

[18] Puri, N., Kumar, B., and Tyagi, H., (2013).Utilization of Recycled Wastes as ingredients in Concrete Mix. International Journal of Innovative Technology and Exploring Engineering, Vol.2, Issue 2 (Jan.,2013), PP 74-78.

[19] Rathod, A. H., and Pitroda, J., (2013). A Study on Recycled Aggregate as a Substitute to Natural Aggregate for Sustainable Development in India Global Research Analysis Vol. 2, Issue 2, Feb., 2013: 73-75.

[20] Sivakumar, N., Muthukumar, S., Sivakumar, V.,owtham, D., and Muthuraj V (2014).Experimental Studies on High Strength Concrete by using Recycled CoarseAggregate. International Journal of Engineering and Science Vol.4, Issue 01 (Jan.,2014), PP 27-36. 63 International Journal for Science, Management and Technology ISSN: 2395- 5856

[21] Vyas, M. C., and Bhatt, R. D., (2012). A TechnoEconomical Study on Recycled Aggregate Concrete.International Journal of Advanced Engineering Technology Vol.III, Issue IV, Oct-Dec., 2012: 107-109.

\section{Tables and Figures}

Table 1: Physical properties of Cement

\begin{tabular}{|c|l|c|}
\hline Sr. No. & \multicolumn{1}{|c|}{ Properties } & Observations \\
\hline 1 & Fineness (90 micron IS Sieve) & 4 percent \\
\hline 2 & Initial setting time & 60 minutes \\
\hline 3 & Final setting time & 380 minutes \\
\hline 4 & Standard consistency & 33 percent \\
\hline 5 & Specific Gravity & 3.15 \\
\hline 6 & 28-days compressive strength & $46.2 \mathrm{Mpa}$ \\
\hline
\end{tabular}

Table 2: Physical properties of Waste marble powder

\begin{tabular}{|c|l|c|}
\hline Sr. No. & Properties & Observations \\
\hline 1. & Color & White \\
\hline 2. & Form & Powder \\
\hline 3. & Specific Gravity & 2.66 \\
\hline 4. & Blaine Fineness & $1500 \mathrm{~m}^{2} / \mathrm{kg}$ \\
\hline
\end{tabular}

Table 3: Physical properties of Recycled Coarse Aggregates

\begin{tabular}{|c|l|c|}
\hline Sr. No. & Properties & Observations \\
\hline 1. & Specific gravity & 2.28 \\
\hline 2. & Impact Value & $18 \%$ \\
\hline 3. & Bulk density & $1422 \mathrm{~kg} / \mathrm{m}^{3}$ \\
\hline
\end{tabular}

Table 4: Physical properties of fine aggregate

\begin{tabular}{|c|l|c|}
\hline Sr. No. & \multicolumn{1}{|c|}{ Properties } & Observations \\
\hline 1. & Fineness modulus of fine aggregate & 2.53 \\
\hline 2. & Specific gravity of fine aggregate & 2.64 \\
\hline 3. & Bulk density of fine aggregate & $1667 \mathrm{~kg} / \mathrm{m}^{3}$ \\
\hline 4. & Water absorption of fine aggregate & $0.80 \%$ \\
\hline
\end{tabular}

Table 5: Physical properties of coarse aggregate

\begin{tabular}{|c|l|c|}
\hline Sr. No. & \multicolumn{1}{|c|}{ Properties } & Observations \\
\hline 1. & Fineness modulus of coarse aggregate & 6.59 \\
\hline 2. & Specific gravity of coarse aggregate & 2.69 \\
\hline 3. & Bulk density of coarse aggregate & $1720 \mathrm{~kg} / \mathrm{m}^{3}$ \\
\hline 4. & Water absorption of coarse aggregate & $0.92 \%$ \\
\hline
\end{tabular}

Table 6: Concrete Mix Design

\begin{tabular}{|l|l|c|c|}
\hline & & Ratio & $\mathbf{~ k g} / \mathbf{m 3}$ \\
\hline a) & Cement Content & 1 & 351 \\
\hline b) & Fine Aggregates Content & 2.03 & 746.56 \\
\hline c) & Coarse Aggregates Content & 3.53 & 1189.82 \\
\hline d) & Water & 0.45 & 157.73 \\
\hline
\end{tabular}

Table 7: Slump Value for different Concrete Mix

\begin{tabular}{|c|c|c|c|c|c|c|}
\hline $\begin{array}{c}\text { Mix } \\
\text { ID }\end{array}$ & Cement & $\begin{array}{c}\text { Marble } \\
\text { Powder }\end{array}$ & $\begin{array}{c}\text { Fine } \\
\text { Aggregate }\end{array}$ & $\begin{array}{c}\text { Coarse } \\
\text { Aggregate }\end{array}$ & $\begin{array}{c}\text { Recycled coarse } \\
\text { aggregate }\end{array}$ & $\begin{array}{c}\text { Slump } \\
\text { in mm }\end{array}$ \\
\hline M1 & 100 & 0 & 100 & 100 & 0 & 110 \\
\hline M2 & 95 & 5 & 100 & 85 & 15 & 98 \\
\hline M3 & 95 & 5 & 100 & 70 & 30 & 92 \\
\hline M4 & 95 & 5 & 100 & 55 & 45 & 88 \\
\hline M5 & 90 & 10 & 100 & 85 & 15 & 91 \\
\hline M6 & 90 & 10 & 100 & 70 & 30 & 8470 \\
\hline M7 & 90 & 10 & 100 & 55 & 45 & 80 \\
\hline M8 & 85 & 15 & 100 & 85 & 15 & 87 \\
\hline M9 & 85 & 15 & 100 & 70 & 30 & 79 \\
\hline M10 & 85 & 15 & 100 & 55 & 45 & 72 \\
\hline
\end{tabular}

Table 8: Compressive Strength Values for various Concrete Mix

\begin{tabular}{|c|c|c|c|c|c|c|c|}
\hline $\begin{array}{c}\text { Mix } \\
\text { ID }\end{array}$ & Cement & $\begin{array}{c}\text { Marble } \\
\text { Powder }\end{array}$ & $\begin{array}{c}\text { Fine } \\
\text { Agg. }\end{array}$ & $\begin{array}{c}\text { Coarse } \\
\text { Agg. }\end{array}$ & $\begin{array}{c}\text { Recycled } \\
\text { coarse Agg. }\end{array}$ & \multicolumn{2}{|c|}{$\begin{array}{c}\text { Compressive } \\
\text { Strength } \\
\left(\mathrm{N} / \mathrm{mm}^{2}\right)\end{array}$} \\
\cline { 6 - 9 } & & & & & & 7 days & 28 days \\
\hline M1 & 100 & 0 & 100 & 100 & 0 & 21.23 & 29.23 \\
\hline M2 & 95 & 5 & 100 & 85 & 15 & 22.31 & 31.87 \\
\hline M3 & 95 & 5 & 100 & 70 & 30 & 23.16 & 34.23 \\
\hline M4 & 95 & 5 & 100 & 55 & 45 & 22.73 & 32.73 \\
\hline M5 & 90 & 10 & 100 & 85 & 15 & 23.89 & 33.44 \\
\hline M6 & 90 & 10 & 100 & 70 & 30 & 25.10 & 36.27 \\
\hline M7 & 90 & 10 & 100 & 55 & 45 & 23.67 & 34.72 \\
\hline M8 & 85 & 15 & 100 & 85 & 15 & 23.01 & 33.18 \\
\hline M9 & 85 & 15 & 100 & 70 & 30 & 23.43 & 34.12 \\
\hline M10 & 85 & 15 & 100 & 55 & 45 & 21.80 & 32.87 \\
\hline
\end{tabular}


International Journal of Science and Research (IJSR)

ISSN (Online): 2319-7064

Index Copernicus Value (2013): 6.14 | Impact Factor (2015): 6.391

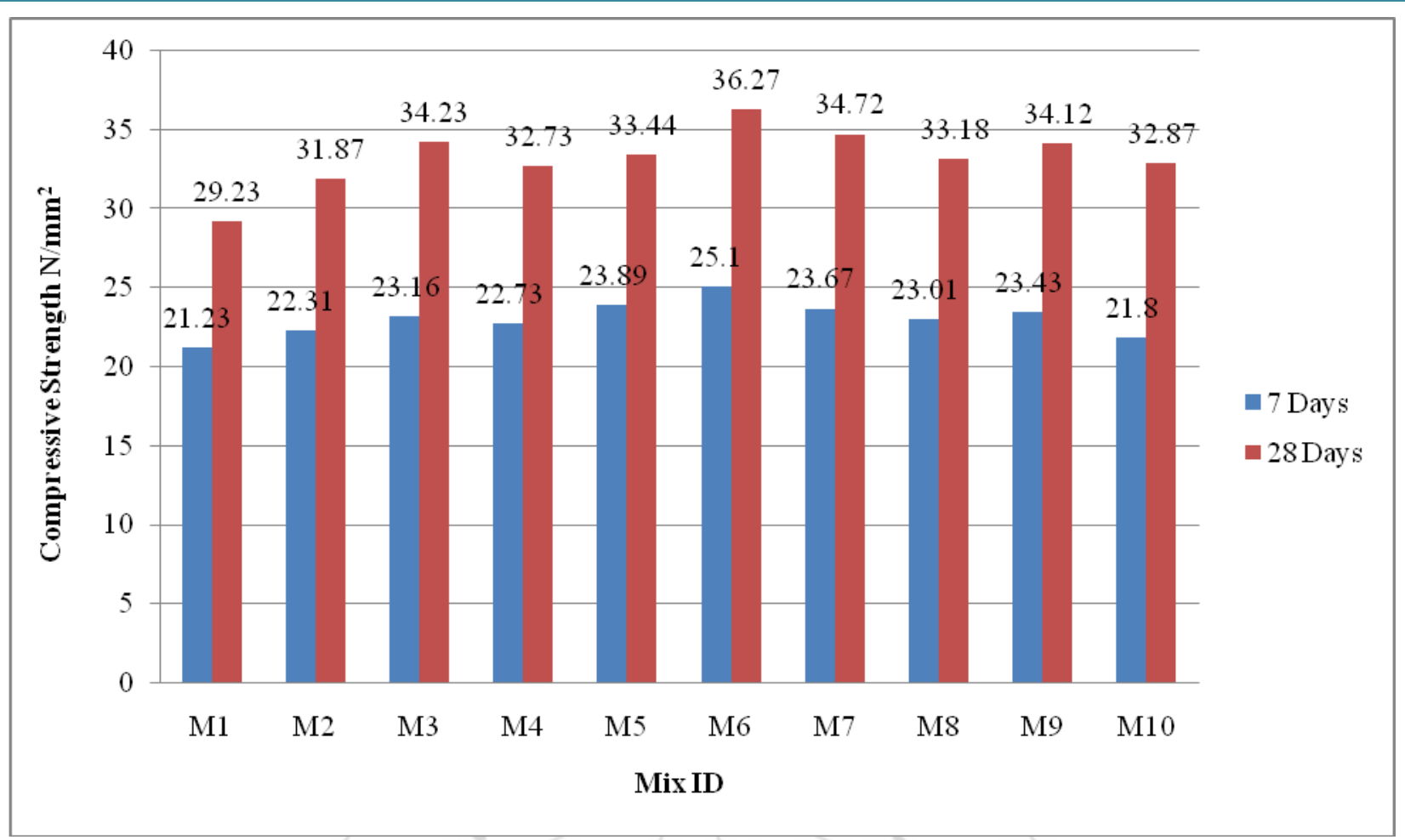

Table 10: Compressive Strength Values for various Concrete Mix

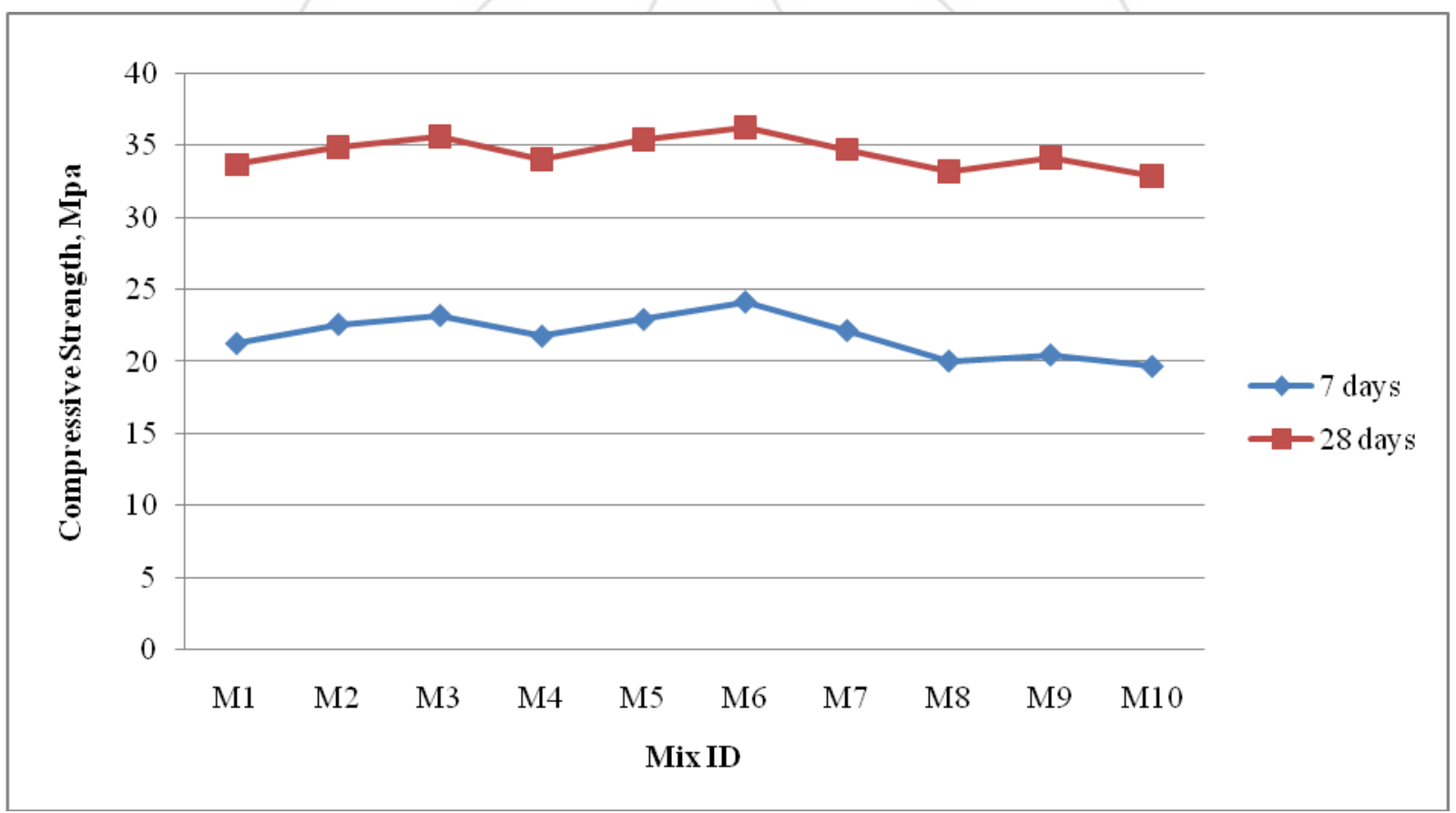

Volume 5 Issue 5, May 2016 


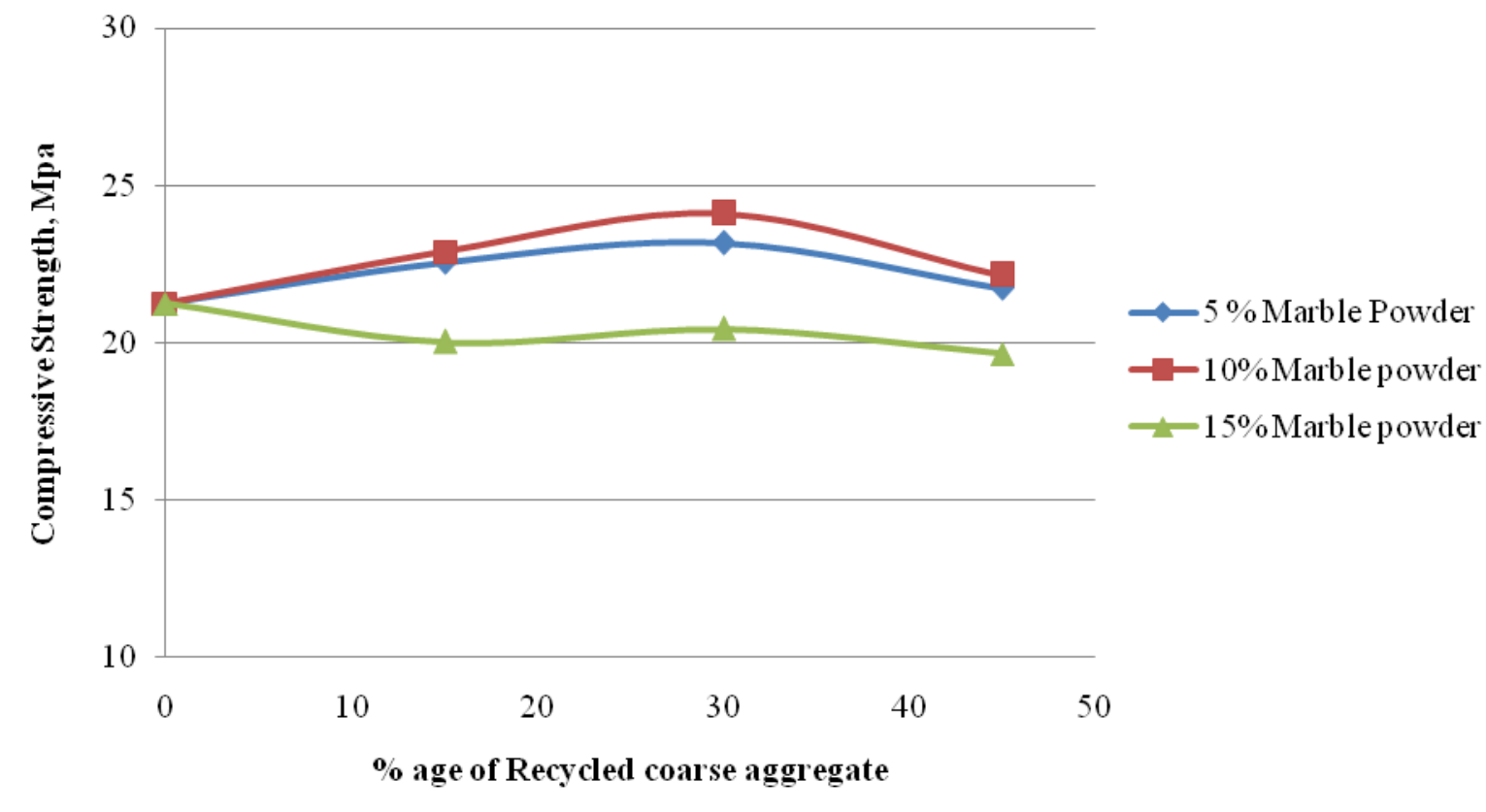

Volume 5 Issue 5, May 2016 www.ijsr.net 